\title{
Pelatihan Penulisan Penelitian Tindakan Kelas (PTK) pada Guru Sekolah Dasar di Kecamatan Sukun Kota Malang
}

\author{
Dwi Fita Heriyawati \\ Universitas Islam Malang \\ dwifitaheriyawati@unisma.ac.id/dwifitah@gmail.com
}

Ifit Novita Sari

Universitas Islam Malang

Naskah diterima: 23 Maret 2020| Naskah disetujui: 15 Mei 2020

\begin{abstract}
This article describes the results of community service by the engagement team of Islamic University of Malang which is conducted toward the teachers of an elementary school in Sukun District, Malang City. The program aims to improve the teachers' ability in writing research in particular using the classroom action research (CAR) method of which conducting the report always became the difficulty for them. Therefore, in this occasion we identify the problems as follows: a) deciding the topic for the CAR, b) creating the title for the research, c) creating research questions, d) creating the stages of the research and also relevant instrumentation to collect the data, e) writing discussion for the results, then composing the suggestion and conclusion from the results. The method of implementing community service is done by carrying out training and practice of writing CAR. From the results of the training, found that it were quite good where elementary school teachers gained experience about writing CAR. The participants were very enthusiastic about the training, so in the end of this activity, it is expected that by conducting this CAR training, they will be able to conduct the research both independently and in groups.
\end{abstract}

Keywords: CAR, mentoring, training

\begin{abstract}
Abstrak
Artikel ini menjelaskan hasil pengabdian masyarakat oleh tim pengabdi dari Universitas Islam Malang yang dilakukan terhadap guru-guru Sekolah Dasar di Kabupaten Sukun, Kota Malang. Pengabdian ini bertujuan untuk meningkatkan kemampuan guru dalam menulis penelitian khususnya menggunakan metode penelitian tindakan kelas (PTK) yang mana melakukan laporan selalu menjadi kesulitan bagi mereka. Oleh karena itu, dalam kesempatan ini kami mengidentifikasi masalah sebagai berikut: a) memutuskan topik untuk CAR, b) membuat judul, c) membuat pertanyaan penelitian, d) menciptakan tahapan penelitian dan juga instrumentasi yang relevan untuk mengumpulkan data, e) menulis diskusi hasil, kemudian menyusun saran dan kesimpulan dari hasil. Metode pelaksanaan pengabdian masyarakat dilakukan dengan melakukan pelatihan dan praktik penulisan PTK. Dari hasil pelatihan, ditemukan bahwa guru Sekolah Dasar memperoleh pengalaman tentang menulis PTK. Para peserta sangat antusias dengan pelatihan ini, sehingga pada akhir kegiatan ini, diharapkan dengan melakukan pelatihan PTK ini, mereka akan dapat melakukan penelitian baik secara mandiri maupun dalam kelompok.
\end{abstract}

Kata Kunci: pelatihan, pendampingan, PTK

2716-0750 (C) 2020 The Author(s).

Published by LP2M INSURI Ponorogo. This is an open access article under the CC BY-SA 4.0 license. doi: 10.37680/amalee.v1i2.302 


\section{Pendahuluan}

Penerapan Kurikulum 2013 berdampak pada kebingungan para pengajar di sekolah-sekolah. Hal ini dikarenakan para guru harus menghadapi siswa dengan metode pengajaran dan media pengajaran yang relatif harus diubah. Strategi pembelajaran yang digunakan pun juga perlu disesuaikan dengan kurikulum yang terbaru yakni kurikulum 2013. Dalam hal ini sudah pasti membuat para guru mengalami kesulitan di dalam pemantapan materi, penyediaan materi belajar, strategi pembelajaran yang digunakan serta media pembelajaran yang digunakan. Terlebih lagi para guru juga dituntut untuk mampu mengerjakan tugas-tugas administratif lainnya.

Heriyawati \& Sulistyo (2016) menjelaskan bahwa untuk menunjang profesionalisme guru Sekolah Dasar, selain guru harus mampu menyusun dan mengembangkan metode, media, dan teknik pembelajaran di dalam kelas, para guru dituntut juga untuk menguasai penelitian yang terkait dengan proses pembelajaran di dalam kelas yang sangat umum disebut dengan penelitian tindakan kelas atau PTK. Pelaksanaan penelitian tindakan kelas ini juga merupakan salah satu upaya untuk membantu meningkatkan kemampuan siswa dalam penguasaan materi pelajaran di sekolah. Penelitian tindakan kelas yang dilaksanakan di dalam kelas juga harus sesuai dengan isi kurikulum 2013. Penelitian tindakan kelas adalah penelitian yang dilakukan untuk mengatasi permasalahan siswa dan pembelajaran yang terjadi di dalam kelas. Penelitian tindakan kelas bertujuan untuk memperbaiki strategi belajar mengajar di dalam kelas. Adapun ciri-ciri penelitian tindakan kelas antara lain: penelitian ini dilakukan oleh guru yang bersangkutan, hal ini berarti bahwa guru tersebut berperan sebagai peneliti dan yang mengetahui lebih banyak tentang masalah apa saja yang terjadi di dalam kelas (Latief, 2003:99). Ciri dari penelitian tindakan kelas yang lain adalah bahwa penelitian dilakukan secara kolaboratif dengan dibantu oleh peneliti yang lain untuk melakukan penelitian tersebut, hal ini dilakukan untuk mengukur reliabitas dari test yang dilakukan. Adapun tujuan dari penelitian tindakan kelas ini adalah untuk membuat perubahan yang bertujuan untuk memperbaiki strategi mengajar serta materi yang diajarkan, hal ini dilakukan untuk memecahkan masalah belajar yang dihadapi oleh siswa.

Dalam proses pembelajaran di dalam kelas untuk siswa Sekolah Dasar sudah mengacu pada tematik di mana seluruh materi pelajaran terintegrasi di dalam tema yang wajib diajarkan kepada siswa, sehingga untuk menyelesaikan permasalahan yang dihadapi oleh siswa di dalam kelas perlu adanya pengembangan kurikulum 2013 yang dilaksanakan atas dasar beberapa prinsip utama antara lain standar kompetensi lulusan yang disusun berdasarka kebutuhan siswa. Standar isi yang disusun berdasarkan kompetensi lulusan yang diturunkan dari standar kompetensi lulusan melalui kompetensi inti. Selanjutnya semua mata pelajaran harus memberikan kontribusi terhadap pembentukan sikap, keterampilan, dan pengetahuan peserta didik. Mata pelajaran disusun berdasarkan kompetensi yang ingin dicapai oleh peserta didik dan semua mata pelajaran terikat oleh kompetensi inti. Selanjutnya diperlukan juga keselarasan tuntutan kompetensi lulusan, isi, proses pembelajaran, dan penilaian. Aplikasi yang taat asas dari prinsip-prinsip ini menjadi sangat penting dalam mewujudkan keberhasilan penerapan Kurikulum 2013 dalam proses belajar mengajar untuk anak Sekolah Dasar.

Berkaitan dengan implementasi kurikulum 2013 di dalam proses belajar mengajar mulai dari pendidikan dasar sampai dengan pendidikan tinggi, maka diperlukan penyiapan materi pembelajaran serta strategi pembelajaran yang lebih sesuai dengan kurikulum tersebut. Proses pembelajaran yang mengacu pada kurikulum 2013 juga perlu dilaksanakan dengan baik. 
Sehubungan dengan hal tersebut, guru juga wajib untuk membuat penelitian tindakan kelas yang akan sangat menunjang profesionalisme guru serta sebagai salah satu upaya untuk memperbaiki proses belajar mengajar yang dilaksanakan di dalam kelas. Penelitian tindakan kelas ini juga harus mengacu pada proses pembelajaran yang dilaksanakan didalam kelas. Tahapan proses pembelajaran serta strategi yang digunakan oleh guru di dalam kelas akan dianalisis tingkat keberhasilannya sampai memenuhi pada hasil yang diharapkan.

Proses pembelajaran yang dilakukan di Sekolah Dasar juga dilakukan secara bertahap. Misalnya kita tidak bisa berharap bahwa siswa Sekolah Dasar kelas 1 bisa membuat sebuah karangan deskripsi dengan sempurna. Pemilihan materi, strategi pengajaran, dan media yang sesuai dan situasi belajar yang menyenangkan haruslah menjadi perhatian utama dalam berhasilnya suatu proses pembelajaran. Proses pembelajaran hendaknya tidak membuat siswa menghafal namun membuat siswa memahami konsep. Dan yang lebih penting adalah bahwa siswa tidak merasakan pembelajaran sebagai suatu beban, melainkan merupakan sebuah situasi yang menyenangkan dan membuat siswa merasa proses belajar yang sedang dilakukan adalah proses yang mengasikan bagi siswa.

Terkait pada pemilihan materi, media dan strategi pembelajaran untuk anak-anak, hendaknya seorang guru juga memahami kaidah pembelajaran yang sesuai untuk anak-anak. Hal ini didukung oleh pendapat Kasihani (2007) yang menyatakan bahwa proses pembelajaran harus didukung dengan media yang memadai agar siswa mudah untuk memahami penjelasan yang diberikan oleh guru. Untuk memenuhi kebutuhan pembelajaran yang menyenangkan tersebut maka diperlukan modifikasi, kreasi, dan inovasi pembelajaran yang dapat dilakukan dengan melaksanakan penelitian tindakan kelas. Sehingga di dalam pelaksanaan penelitian tindakan kelas ditemukan hal baru sebagai bentuk upaya inovasi pembelajaran dan pengajaran bagi siswa Sekolah Dasar. Selain itu, dengan pelaksanaan penelitian tindakan kelas para guru akan memiliki kemampuan menganalisa kesulitan siswa dalam menguasai materi pembelajaran dan menemukan ide-ide kreatif yang dapat bermanfaat jika diterapkan dalam proses belajar mengajar di dalam kelas.

Pembahasan tentang pembelajaran untuk anak-anak tentunya akan sangat berbeda jauh prosesnya dengan pembelajaran pada orang dewasa. Oleh karena itu metode dan teknik yang digunakan sebaiknya dipilih dan disesuaikan dengan kemampuan yang ingin dicapai (Heriyawati \& Sulistyo, 2016). Profesionalisme seorang pendidik dalam mengembangkan dan memanfaatkan metode dan teknik pengajaran sangatlah dibutuhkan agar proses belajar mengajar dapat berjalan dengan lebih baik. Oleh karena itulah penulisan penelitian tindakan kelas menjadi suatu kebutuhan bagi guru-guru Sekolah Dasar dalam rangka meningkatkan profesionalitas guru dan membuat inovasi pembelajaran yang lebih aktif, kreatif dan inovatif yang dapat diterapkan di kelas dalam rangka membangun suasana belajar mengajar yang lebih menyenangkan dan lebih bervariasi.

Berdasarkan latar belakang di atas maka tim pengabdi bermaksud melaksanakan pengabdian masyarakat dengan judul "Pelatihan Penulisan Penelitian Tindakan Kelas (PTK) pada Guru Sekolah Dasar di Kecamatan Sukun Kota Malang”.

\section{Permasalahan Mitra}

Berdasarkan analisis situasi dan kesepakatan dengan mitra (Kelompok Kerja Guru gugus 9) maka permasalahan yang dihadapi oleh guru-guru SD terkait dengan penulisan penelitian 
tindakan kelas dan segera harus mendapatkan solusi untuk mengatasi permasalahan tersebut dapat dijelasakan sebagai berikut:

\section{Proses Pemilihan Topik dan Judul PTK}

Selama ini guru-guru di Sekolah Dasar Kecamatan Sukun Kota Malang mengalami kesulitan dalam menentukan topik yang akan diangkat menjadi penelitian tindakan kelas. Selain itu para guru juga mengalami kesulitan di dalam membuat judul penelitian tindakan kelas yang sesuai dengan topik yang mereka ambil.

\section{Merumuskan Masalah Penelitian Tindakan Kelas}

Setelah menentukan topik dan judul untuk melakukan penelitian tindakan kelas, guruguru juga mengalami kesulitan dalam merumuskan masalah penelitian tindakan kelas. Sehingga perlu diberikan pelatihan tentang tata cara membuat rumusan masalah penelitian tindakan kelas.

\section{Metode Penelitian Tindakan Kelas dan Instrument Penelitian}

Para guru juga perlu diberi ketrampilan untuk menerapkan tahapan penelitian tindakan kelas sesuai dengan siklus pelaksanaan penelitian tindakan kelas, yaitu; perencaanan penelitian, pelaksanaan penelitian, observasi, dan refleksi hasil penelitian (Kemmis, S. \& McTaggart, R., 1988). Selain itu para guru Sekolah Dasar juga mengalami kesulitan dalam membuat instrument yang akan digunakan untuk mencari data penelitian.

\section{Menulis Hasil Penelitian Tindakan Kelas, Pembahasan, Simpulan, dan Saran}

Setelah pelaksanaan penelitian tindakan kelas dilakukan, guru-guru juga mengalami kesulitan dalam menuliskan hasil penelitian, pembahasan, kesimpulan dan saran. Pada umumnya mereka mengalami kesulitan dalam membedakan hal apa saja yang perlu dijabarkan dalam pembahasan dan temuan hasil penelitian.

Dengan melihat permasalahan tersebut maka sangat perlu diupayakan pemecahan permasalahan yang dihadapi guru-guru Sekolah Dasar gugus 9 Kecamatan Sukun, Kota Malang. Berdasarkan kesepakatan dengan mitra, maka permasalahan utama yang segera diselesaikan adalah: 1) Menentukan topik dan judul penelitian tindakan kelas; 2) Merumuskan masalah pada penelitian tindakan kelas 3) Menjelasakan secara detail bagaimana tahapan untuk menerapkan penelitian tindakan kelas, Serta pembuatan instrument yang akan digunakan untuk mengumpulkan data penelitian. 4) Menuliskan dan menjabarkan temuan penelitian, pembahasan, kesimpulan dan saran untuk laporan penelitian.

\section{Target dan Luaran}

Berdasarkan uraian di atas, maka jenis luaran yang ditargetkan adalah bahwa para guru akan mendapatkan tehnik pengajaran yang inovatif serta media pembelajaran yang lebih variatif yang bisa mereka implementasikan pada para siswa dalam pengajaran di dalam kelas dan juga bisa mereka sampaikan kepada rekan guru yang lain. Selain itu mereka juga akan memperoleh ide lebih banyak lagi untuk menetukan topik dan judul penelitian tindakan kelas dalam rangka meningkatkan profesionalisme guru serta meningkatkan kemapuan mengajar yang lebih inovatif bagi anak-anak. Lebih jauh lagi para guru bisa mengembangkan tehnik tersebut dan menjadikannya sebagai topik 
untuk penelitian tindakan kelas di masa yang akan datang.

\section{Kriteria}

Ketrampilan dalam pengembangan materi pembelajaran sesuai dengan kurikulum 2013 untuk Sekolah Dasar dapat meningkat. Selanjutnya, para guru Sekolah Dasar dapat dengan mudah menyeleksi topik yang menarik yang akan digunakan untuk penelitian tindakan kelas.

\section{Indikator}

Menguasai karakteristik penelitian tindakan kelas dan mengenali instrument PTK yang sesuai dengan jenis mata pelajaran yang diajarkan pada siswa

\section{Tolok Ukur}

Menggunakan dan mengembangkan strategy dan media pembelajaran yang sesuai untuk melaksanakan penelitian tindakan kelas bagi guru-guru Sekolah Dasar. Guru-guru juga mampu mengembangkan instrument penelitian tindakan kelas sesuai dengan materi pelajaran yang diajarkan kepada siswa.

\section{Keuntungan Kegiatan}

Kegiatan ini memberikan dampak positif bagi guru-guru Sekolah Dasar Kecamatan Sukun, Kota Malang, bagi Perguruan tinggi dan bagi pemerintah daerah khususnya dinas Pendidikan Kota Malang, baik secara sosial, maupun peningkatan kemampuan akademik guru-guru Sekolah Dasar. Adapun dampak positif yang dapat diraih adalah:

1. Meningkatkan kemampuan guru-guru Sekolah Dasar dalam membuat penelitian tindakan kelas.

2.Dari hasil penelitian tindakan kelas yang dilakukan oleh guru-guru Sekolah Dasar, dapat dijadikan sumber yang akurat dalam inovasi pengajaran didalam kelas dan membantu guru-guru untuk memecahkan kesulitan siswa dalam proses belajar mengajar didalam kelas.

3. Terjalinnya kerjasama secara berkelanjutan antara Universitas Islam Malang dengan Guru-guru Sekolah Dasar Kecamatan Sukun, Kota Malang, khususnya gugus 9 dan Dinas Pendidikan Kota Malang.

4. Meningkatkan kreativitas dan inovasi Guru-guru Sekolah Dasar Kecamatan Sukun, Kota Malang, dalam membuat penelitian tindakan kelas dan pelaporannya.

\section{Metode Pelaksanaan}

Metode yang digunakan dalam pengabdian untuk guru-guru Sekolah Dasar dalam meningkatkan dan memperkenalkan teknik dan tata cara penulisan penelitian tindakan kelas adalah:

a) Pemberian materi dan informasi mengenai penelitian tindakan kelas terkait dengan kurikulum yang diterapkan. Kegiatan ini dimaksudkan untuk memberi informasi kepada para pendidik yang mungkin belum mengetahui teori penelitian tindakan kelas serta pengembangannya. Kegiatan pelatihan penulisan Penelitian Tindakan Kelas (PTK) dilaksanakan selama 3 hari sejak tanggal 16-18 Oktober 2019. Pelaksanaan kegiatan pelatihan ini bertempat di SDN Tanjungrejo 3 Kecamatan Sukun Kota Malang. Kegiatan pelatihan ini melibatkan 30 orang guru yang terdiri dari perwakilan tiap Sekolah Dasar di wilayah gugus 9, Kecamatan Sukun, Kota Malang. 
b) Kegiatan kemudian dilanjutkan dengan pengenalan strategi pembelajaran maupun media pembejaran yang dapat digunakan untuk membuat penelitian tindakan kelas. Kegiatan ini dimaksudkan supaya mereka dapat meningkatkan kemampuan dalam proses pengajaran. Sehingga guru-guru memiliki pengetahuan tentang berbagai macam metode dalam mengajar untuk siswa-siswi Sekolah Dasar serta mampu mengembangkannya menjadi sebuah laporan hasil penelitian tindakan kelas. Didalam pelaksanaan pelatihan penulisan Penelitian Tindakan Kelas ini tim pengabdi memberikan bekal materi kepada peserta pelatihan berupa Modul yang dibuat oleh tim pengabdi dan materi PPT yang ditayangkan untuk memudahkan proses pelaksanan pelatihan penulisan penelitian tindakan kelas ini.

c) Selanjutnya tim pengabdi memberikan contoh pemilihan topik dari strategy pembelajaran yang telah diterapkan oleh guru-guru dalam proses belajar mengajar. Para guru berlatih membuat instrument penelitian tindakan kelas dan mulai berlatih untuk menulis penelitian tindakan kelas. Membuat lembar observasi dan pertanyaan yang dibutuhkan pada saat melakukan observasi. Mengumpulkan tes dan materi pelajaran yang seusai dengan topik penelitian tindakan kelas yang akan dilaksanakan oleh guru-guru, serta berlatih membuat kuestioner dan interview sesuai dengan kebutuhan penelitian yang akan dilaksanakan oleh para guru. Pada tahap awal, para guru membuat rumusan masalah, menentukan tujuan penelitian, menentukan kriteria keberhasilan dari penelitian, serta menentukan implementasi penelitian yang akan dilaksanakan. Pada akhir dari kegiatan ini para guru diminta untuk mempraktekkan membuat penelitian tindakan kelas yang diambil dari hasil kegiatan belajar mengajar mereka. Laporan singkat hasil penelitian yang dilakukan oleh para guru akan dirumuskan menjadi sebuah laporan penelitian tindakan kelas. Dan akan dibuat artikel penelitian hasil penelitian tindakan kelas.

d) Tim pengabdi juga melakukan pendampingan untuk penulisan proposal PTK yang dilakukan oleh guru-guru di wilayah gugus 9 Kecamatan Sukun, Kota Malang. Pendampingan ini merupakan praktek langsung bagi para guru Sekolah Dasar yang menjadi peserta pelatihan untuk menuliskan ide penelitian tindakan kelas yang dibuat oleh guru-guru Sekolah Dasar. Kegiatan pendampingan ini dilaksanakan selama 2 hari.

\section{Hasil dan Pembahasan}

Dari pelatihan membuat Penelitian Tindakan Kelas sebagai salah satu untuk meningkatkan kemampuan guru-guru Sekolah Dasar dalam bidang penelitian di lingkungan Sekolah Dasar Kecamatan Sukun Kota Malang, dapat diambil beberapa poin hasil yaitu sebagai berikut.

a) Peserta sangat antusias dan bersemangat dalam mengikuti pelatihan penulisan penelitian tindakan kelas, hal ini bisa diliat dari ketertarikan peserta dalam memberikan pertanyaan, komentar, dan saran pada sesi tanya jawab. Oleh karena itu, perlu adanya program-program yang berkelanjutan dari pelatihan yang telah diadakan. 


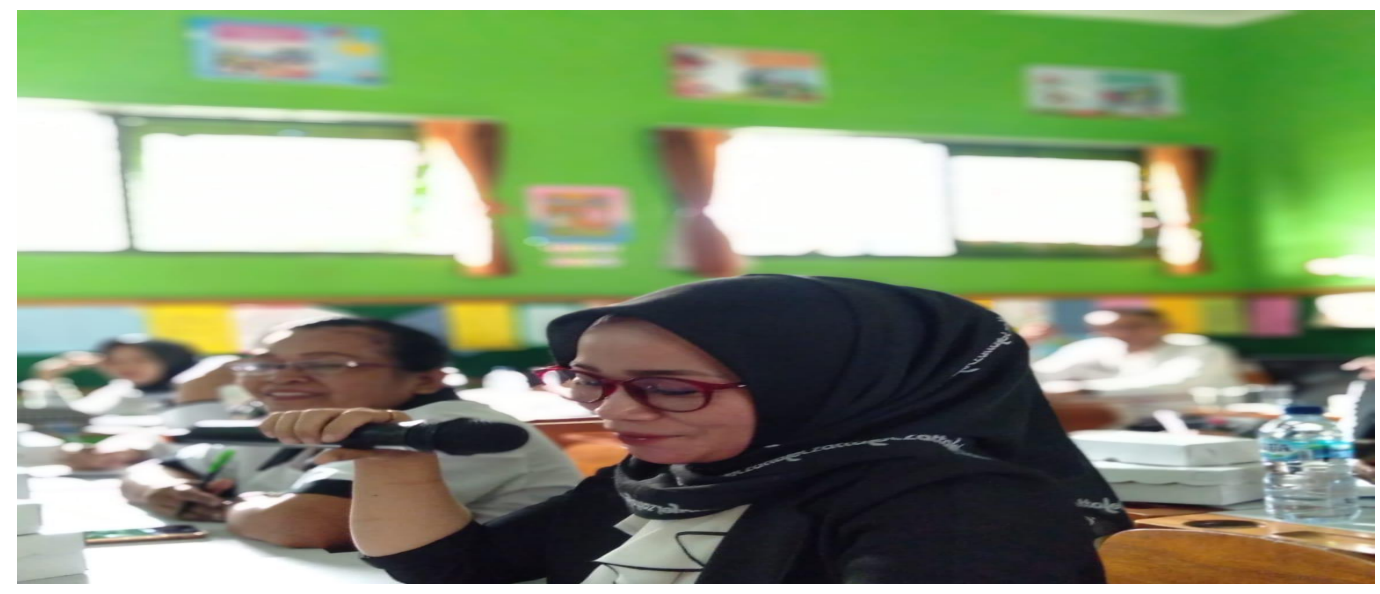

Gambar 1: Komentar, saran dan pertanyaan dari peserta pelatihan

b) Peserta menjadi paham dan bisa mempraktekkan cara menentukan topik penelitian, membuat judul penelitian tindakan kelas dan mempraktekkannya dalam bentuk proposal yang sederhana. Dari hal ini, maka bagi para peserta perlu menstimulasi diri mereka masing-masing untuk lebih kreatif lagi dalam mencari topik penelitian tindakan kelas dan menentukan judul penelitian tindakan kelas yang akan mereka tulis untuk keperluan guru-guru dalam mengurus kepangkatan akademik. Kemudian dari tim pelatih juga diharapkan lebih aktif lagi dalam melakukan pelatihan-pelatihan yang sejenis.

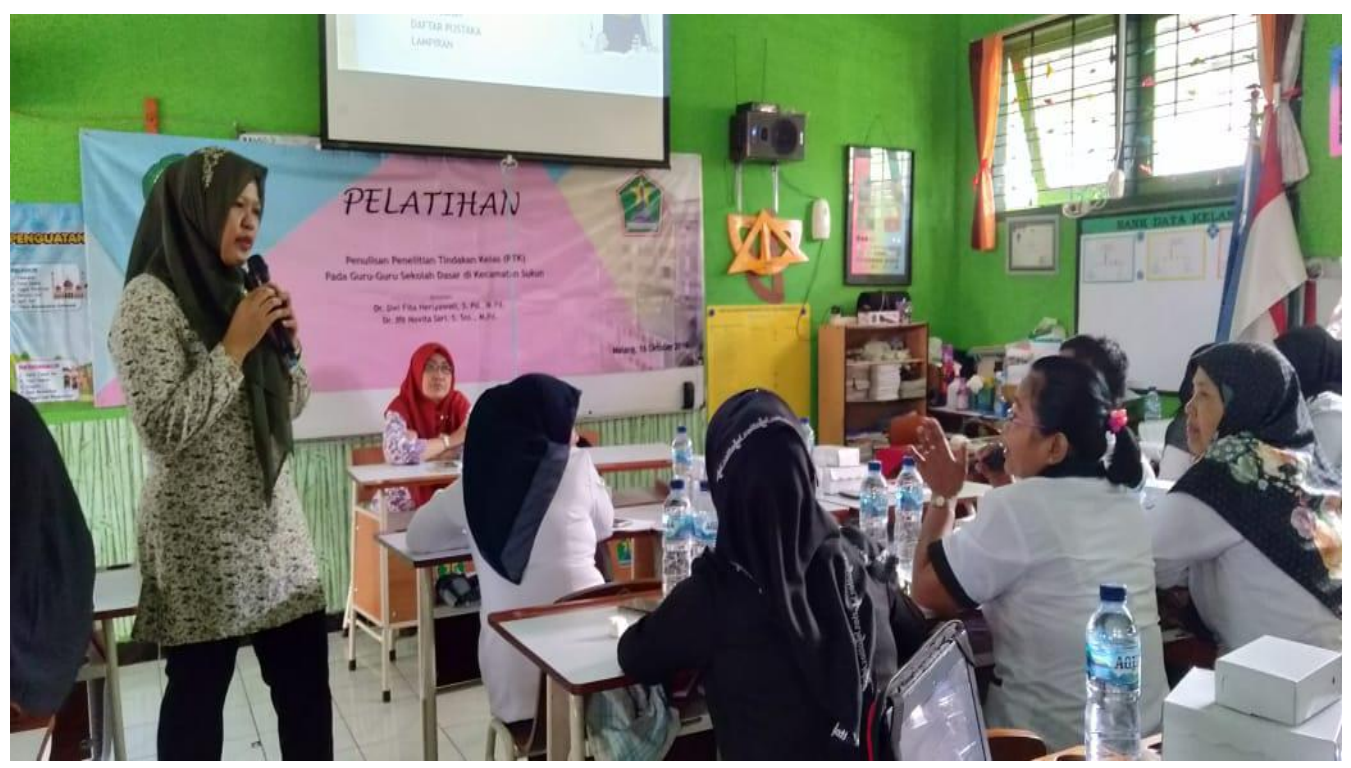

Gambar 2: pelaksanaan pelatihan, sesi pemaparan materi

c) Peserta tidak hanya mengetahui cara menentukan topik penelitian dan membuat judul penelitian tindakan kelas, tetapi juga dibekali kemampuan merumuskan pertanyaan penelitian tindakan kelas, serta membuat metodologi penelitian dengan runtut dan terarah sesuai dengan prosedur pelaksanaan penelitian tindakan kelas.

d) Cara penyampaian yang inovatif, kreatif, dan menarik akan sangat mempengaruhi hasil dari pelaksanaan pelatihan, walaupun dengan materi yang sama, jika pelatih dapat menyampaikan dengan model dan cara yang berbeda, yang lebih menarik, maka peserta pun akan lebih mudah dalam menerima materi pelatihan, khususnya untuk pelatihan penulisan penelitian tindakan kelas. 
e) Peserta pelatihan juga diajarkan tata cara pembuatan instrumen penelitian yang akan digunakan untuk mengambil data pada penelitian tindakan kelas, yaitu berupa kuestioner dan interview. Mereka dilatih untuk membuat daftar pertanyaan dalam bentuk kuestioner dan interview sesuai dengan kebutuhan penelitian yang akan dilaksanakan. Para guru Sekolah Dasar juga dilatih Membuat lembar observasi serta daftar pertanyaan yang dibutuhkan pada saat melakukan observasi. Guru-guru juga mengidentifikasi dan mengumpulkan tes dan materi pelajaran yang seusai dengan topik penelitian tindakan kelas yang akan dilaksanakan oleh guru-guru.

f) Peserta pelatihan juga diberikan materi tentang tata cara menuliskan pembahasan dan kesimpulan dan saran yang akan diterapkan pada pelaporan hasil penelitian tindakan kelas.

g) Peserta juga memahami berbagai macam cara menentukan topik yang dapat digunkan untuk menulis penelitian tindakan kelas, dan peserta jadi lebih giat dan bersemangat untuk membuat penelitian tindakan kelas. Mereka merasa bahwa penelitian tindakan kelas tidaklah sesulit yang mereka pikirkan selama ini. Diakhir kegiatan pealtihan dan pendampingan penulisan penelitian tindakan kelas ini, masing-masing peserta sudah mempunyai ide untuk menulis PTK, rumusan masalah, serta intrument yang akan digunakan untuk mengambil data penelitian.

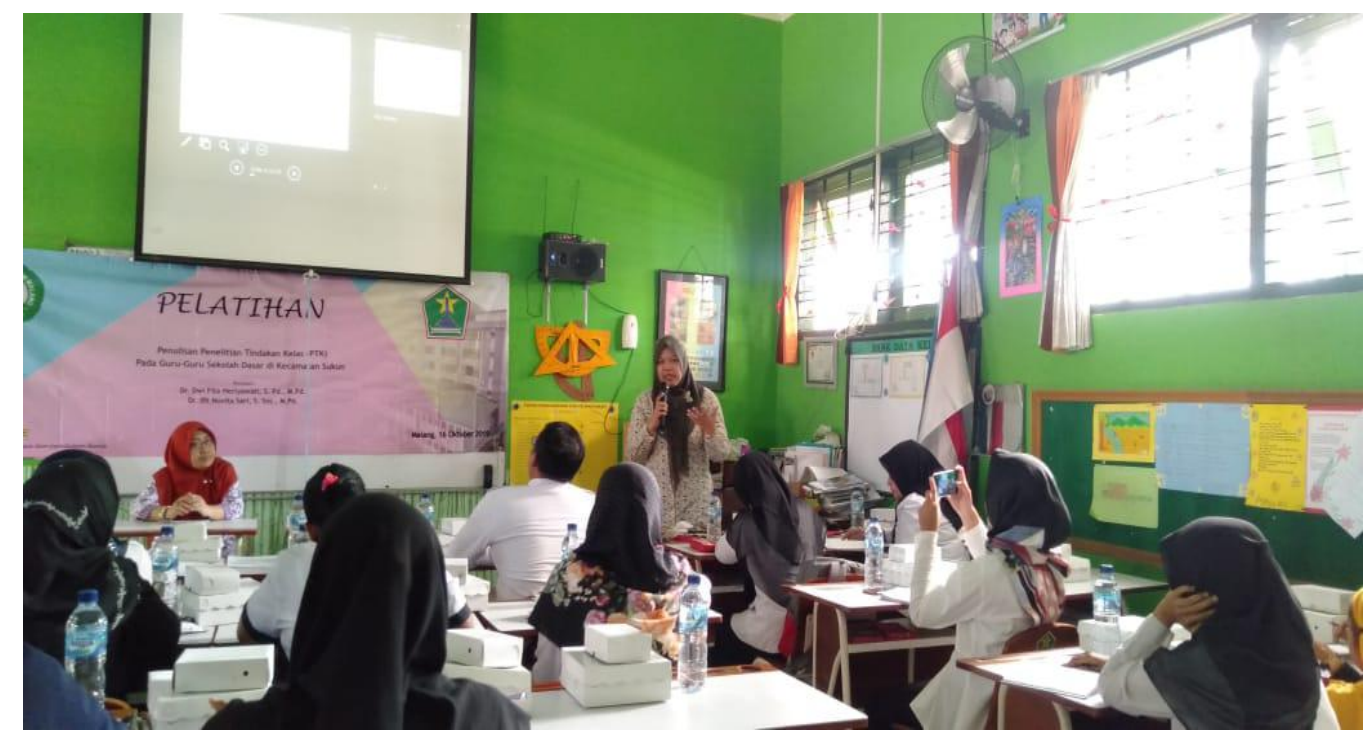

Gambar 3: Pelaksanan Pelatihan dan Pendampingan Penulisan PTK

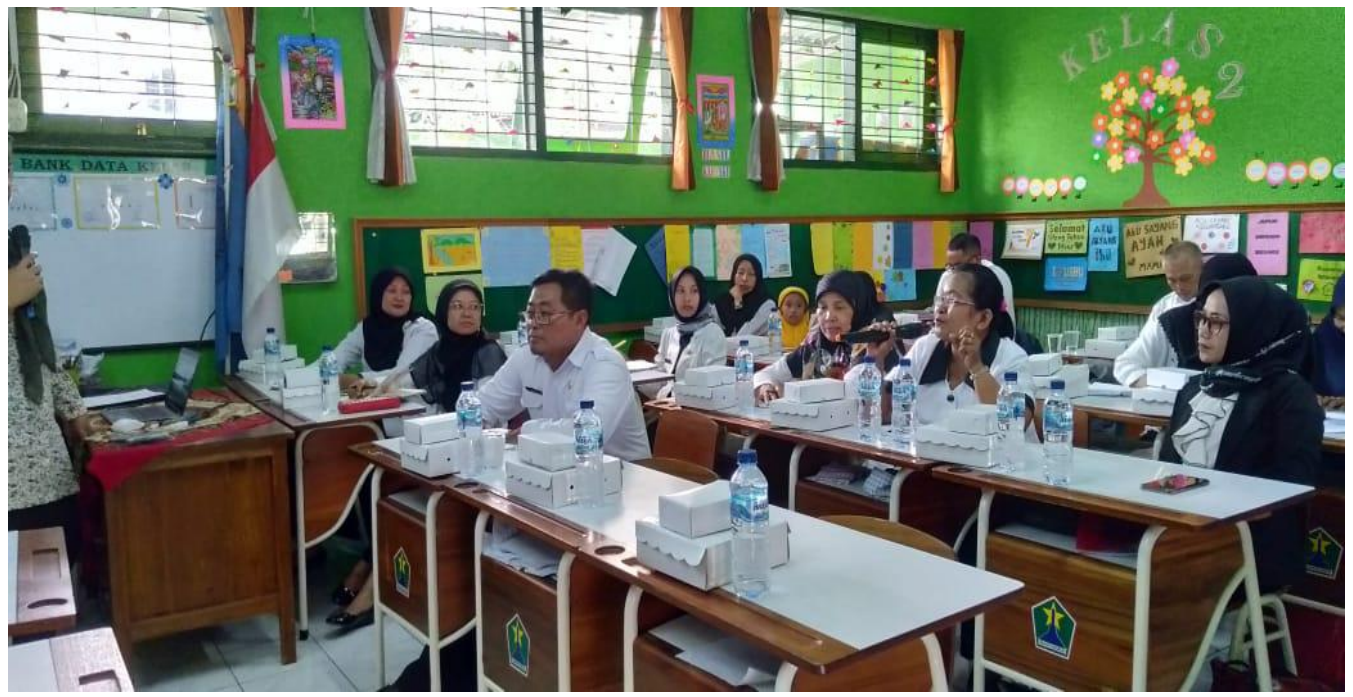

Gambar 4: Sesi tanya jawab pada Pelatihan Penulisan PTK 


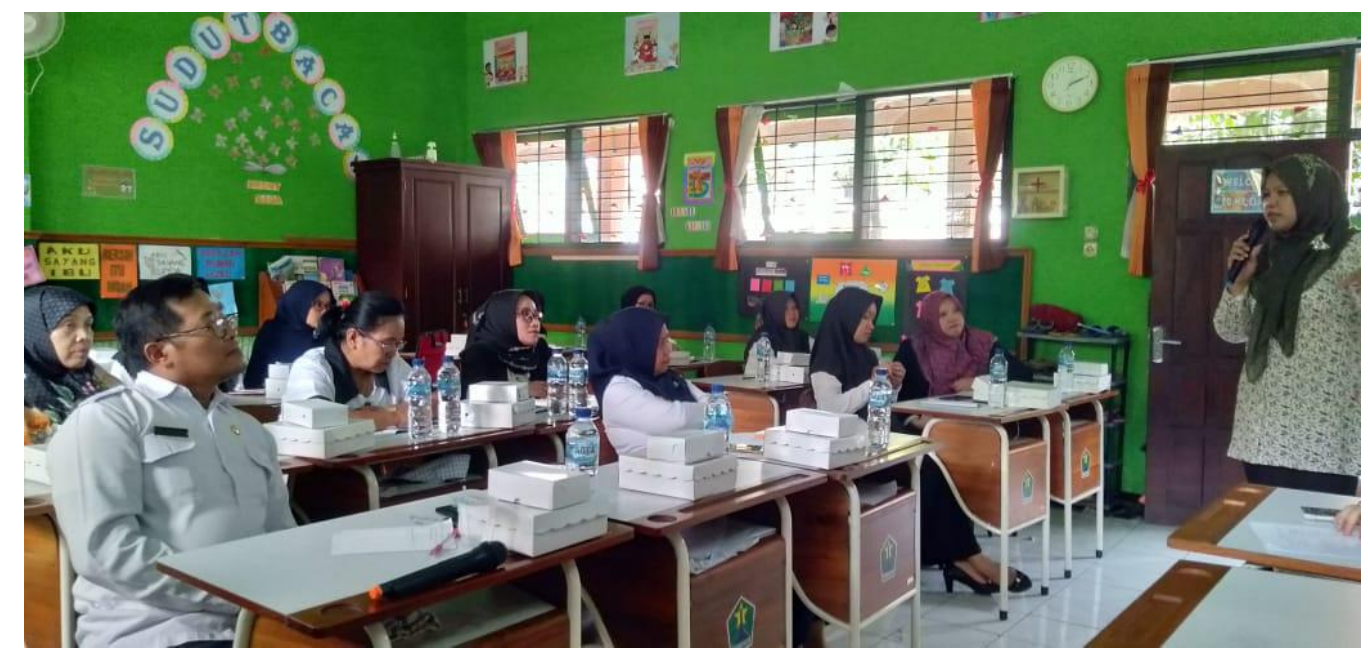

Gambar 5: Penyampaian Materi

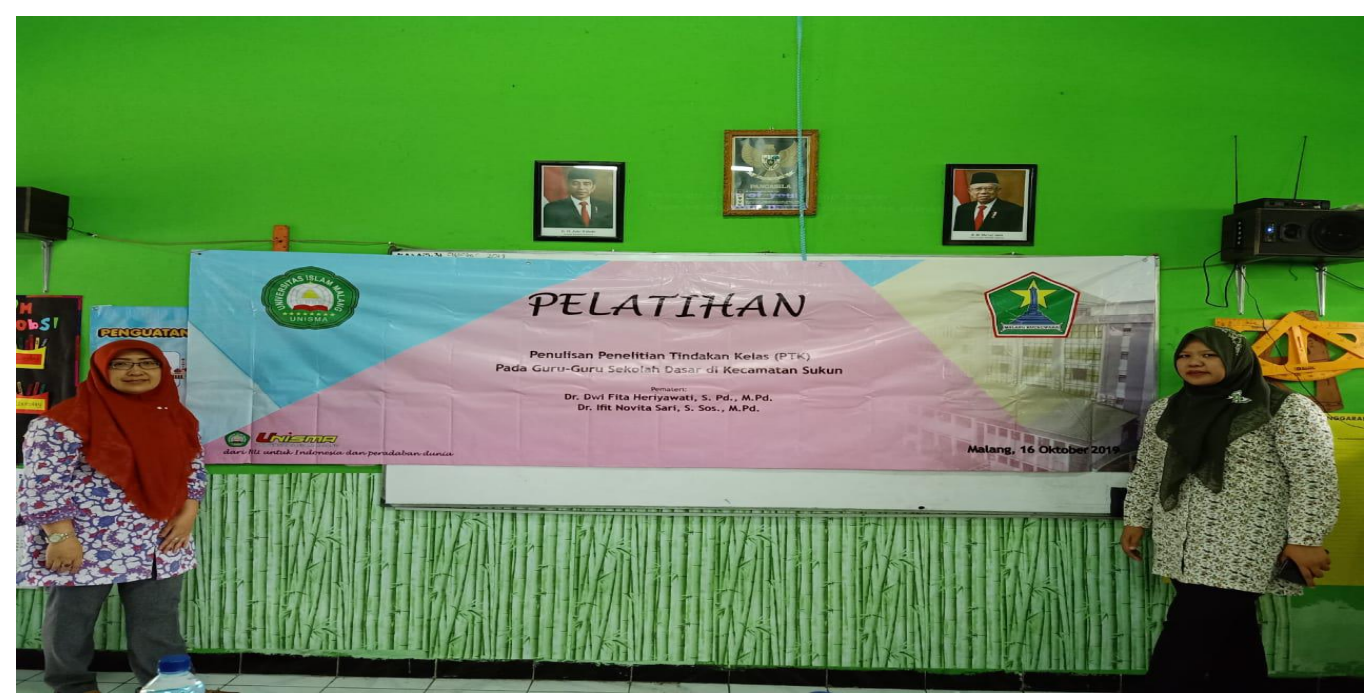

Gambar 6 : Pelaksanaan Pealtihan Penelitian Tindakan Kelas

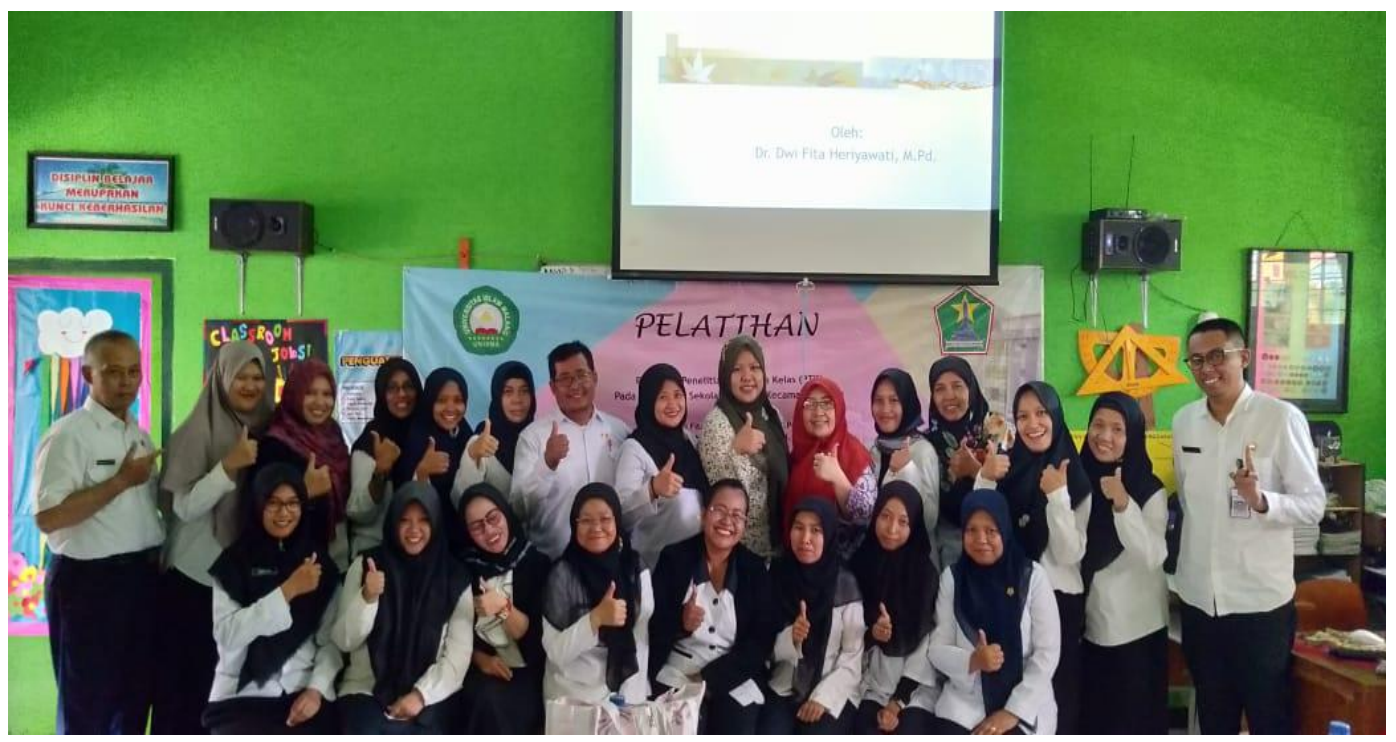

Gambar 7: Pelaksanaan Pelatihan Penelitian Tindakan Kelas 


\section{Kesimpulan}

Adapun kesimpulan yang dapat diambil dari hasil pelaksanaan kegiatan pengabdian pada masyarakat kali ini dapat dijabarkan sebagai berikut:

a) Guru-guru SD di Kecamatan Sukun Malang sebagai peserta pelatihan sangat antusias dalam mengikuti kegiatan pelatihan pembuatan Penelitian Tindakan Kelas yang diberikan oleh tim pengabdi.

b) Guru-guru SD di Kecamatan Sukun Malang mampu menentukan topik dan judul untuk penelitian tindakan kelas (PTK) yang akan mereka laksanakan. Serta mampu mengidentifikasi dan merumuskan masalah penelitian serta tahapan-tahapan pelaksanaan penelitian tindakan kelas (PTK).

c) Pelatihan membuat Penelitian Tindakan Kelas yang diberikan tim pengabdi dapat memberikan bekal bagi guru-guru SD untuk membuat Penelitian Tindakan Kelas yang akan bermanfaat bagi para guru untuk kenaikan pangkat akademik. Selain itu, para guru Sekolah Dasar juga merasa bahwa membuat penelitian tindakan kelas tidak sesulit seperti anggapan mereka selama ini.

d) Guru-guru SD di Kecamatan Sukun Kota Malang dapat memahami tata cara penulisan Penelitian Tindakan Kelas, menentukan topik penelitian, membuat judul penelitian, serta membuat pertanyaan untuk Penelitian Tindakan Kelas dengan lebih mudah dan menyenangkan. Mereka merasa bahwa membuat Penelitian Tindakan Kelas tidaklah sesulit dan serumit yang mereka pikirkan selama ini.

\section{Saran}

Adapun saran yang bisa disampaikan oleh tim pengabdi terkait dengan pelaksanaan kegiatan Pengabdian Kepada Masyarakat ini adalah sebagai berikut:

a) Pelatihan kali ini hanya terbatas pada guru-guru SD gugus 9 di Kecamatan Sukun, Kota Malang yang terdiri dari 7 Sekolah Dasar, yang masing- masing sekolah mengirimkan perwakilan guru sebanyak 3 orang ditambah dengan peserta dari guru-guru sekolah yang ditempati pelaksanaan pelatihan dengan jumlah total peserta pelatihan sebanyak 30 orang, sehingga pelatihan selanjutnya diharapkan dapat menjangkau sampel yang lebih luas seperti semua guru-guru Sekolah Dasar se-kecamatan Sukun, Kota Malang.

b) Pelatihan pembuatan Penelitian Tindakan Kelas yang dilaksanakan selama 3 (tiga) hari sejak tanggal 16-18 Oktober 2019 ini dirasakan masih kurang, karena peserta pelatihan masih perlu pendampingan khusus agar mereka benar-benar memahami pembuatan Penelitian Tindakan Kelas dan dapat dengan mudah dan lancar dalam membuat Penelitian Tindakan Kelas (PTK).

\section{Pernyataan}

Kegiatan pengabdian pada masyarakat ini dilaksanakan dengan menggunakan dana hibah institusi (HIMA-Pengabdian pada Masyarakt, Universitas Islam Malang). Oleh karena itu tim Pengabdi menyampaikan terima kasih yang sebesar-besarnya kepada Universitas Islam Malang yang telah mendukung terlaksananya kegiatan pengabdian pada masyarakat ini. 


\section{Daftar Pustaka}

Dasna Wayan, I. (2007). Penelitian Tindakan Kelas (PTK) (Classroom Action Research); sebagai Upaya Meningkatkan Kualitas Pembelajaran. Malang: Pusat Penelitian Pendidikan, Lembaga Penelitian Universitas Negeri Malang.

Dasna, I.W., (2008). Penelitian Tindakan Kelas (PTK), Materi Pendidikan dan Latihan Profesi Guru (PLPG) di PSG Rayon 15, Malang: Universitas Negeri Malang

Hammersley, M. (Ed.). (1986). Case Studies in Classroom Research. Philadelphia: Open University Press.

Heriyawati, D. F. \& Sulistyo, T. (2016). Pelatihan Pembuatan Media Pembelajaran Bahasa Pada Guru-guru SD dan TK Kecamatan Sukun Malang. Jurnal Pemberdayaan Masyarakat (JPM). Vol.1 No.1. November 2016.

Hopkins, D. (1993). A Teacher's Guide to Classroom Research (2 ${ }^{\text {nd }}$ ed.). Philadelphia: Open University Press.

Kemmis, S. \& McTaggart, R. (1988). The Action Research Planner. Third Edition.Victoria: Deakin University Press.

Kasbolah, Kasihani. (1999). Penelitian Tindakan Kelas (PTK). Jakarta. Direktorat Jendral Pendidikan Tinggi. Proyek Pendidikan Guru Sekolah Dasar. IBRD:LOAN-IND.

Kerlinger, Fred N. (1990). Asas-Asas Penelitian Behavioral. Terjemahan Landung R. Simatupang. Yogyakarta: Gajah Mada University Press.

Kristiyanto Agus. (2010). Penelitian Tindakan Kelas dalam Pendidikan Jasmani dan Kepelatihan Olahraga. Surakarta: Sebelas Maret University Press.

Latief, Adnan. (2003). Penelitian Tindakan Kelas Pembelajaran Bahasa Inggris. Jurnal Ilmu Pendidikan, Jilid10, No. 2. Juni 2003.

Muhtar, Andi. (1995). Why Does Indonesia Need English?. ELE Journal, Vol. 1 No 1. July 1995. Malang. English Education Department. IKIP Malang.

Suyanto, Kasihani. (2007). Teaching English to Young Learners in Indonesia. Jurnal Ilmu Pendidikan, Agustus 2001, Jilid 8, Nomor 3. Malang :UM

Sudarsono, FX. (2001). Aplikasi Penelitian Tindakan Kelas. Jakarta: Pusat antar Universitas untuk Peningkatan dan Pengembangan Aktivitas Instruksional Dirjen Dikti.

Suharsimi, A., Suhardjono, dan Supardi, (2010). Penelitian Tindakan Kelas, Jakarta:PT. Bumi Aksara.

Tim Pelatih Proyek PGSM. (1999). Penelitian Tindakan Kelas (Classroom Action Research). Jakarta: Departemen Pendidikan dan Kebudayaan Dirjen Dikti Proyek Pengembangan Guru Sekolah Menengah. 